\title{
Diversity, Prevalence, and Virulence of Colletotrichum Species Associated with Lima Bean in Brazil
}

\author{
Gerusa R. S. Cavalcante, ${ }^{1}$ Beatriz M. Barguil, ${ }^{2}$ Willie A. S. Vieira, ${ }^{1}$ Waléria G. Lima, ${ }^{1}$ Sami J. Michereff, ${ }^{1}$ Vinson P. Doyle, ${ }^{3}$ \\ and Marcos P. S. Câmara ${ }^{1, \dagger}$ \\ ${ }^{1}$ Departamento de Agronomia, Universidade Federal Rural de Pernambuco, 52171-900, Recife, PE, Brasil \\ ${ }^{2}$ Departamento de Biologia, Universidade Estadual do Piauí, 64003-120, Teresina, PI, Brasil \\ ${ }^{3}$ Department of Plant Pathology and Crop Physiology, Louisiana State University AgCenter, Baton Rouge, LA, U.S.A.
}

\begin{abstract}
Anthracnose is one of the most important diseases of lima bean in Brazil. Previously, the disease was attributed exclusively to Colletotrichum truncatum. Therefore, this work aimed to characterize the diversity, prevalence, and virulence of Colletotrichum spp. associated

were pathogenic to lima bean. In addition, several strains were found that represent novel lineages, presented here as Colletotrichum lineages 1 to 5. C. truncatum is the prevailing species and more virulent than all other species studied.
\end{abstract} with anthracnose in lima bean in Brazil. Here, we report the species C. truncatum, C. brevisporum, C. lobatum, C. plurivorum, and C. musicola in association with anthracnose of lima bean. All species
Keywords: anthracnose, multilocus, Phaseolus lunatus, phylogenetic analysis, species delimitation.
Lima bean (Phaseolus lunatus L.) is an important source of food and income for small farmers in Brazil, occupying 20,209 ha and yielding 3,637 t/ha in 2016 (Instituto Brasileiro de Geografia e Estatística 2017). P. lunatus is the second most consumed species of the genus Phaseolus in the world, behind the common bean (P. vulgaris) (Maquet et al. 1999). The crop is affected by several diseases; however, anthracnose caused by Colletotrichum spp. is one of the most important diseases of lima bean in Brazil (Carvalho et al. 2015; Paula Júnior et al. 1995).

The anthracnose symptoms on lima bean begin with reddish spots along the veins on the adaxial side of the leaves and on young stems and petioles. On the pods, the lesions are depressed, large, and reddish, with developing acervuli. Reddish and necrotic lesions can also be seen on the hypocotyl, petiole, and leaf surface, resulting in wrinkled leaves (Ballhorn et al. 2010; Carvalho et al. 2015).

Until recently, lima bean anthracnose has been attributed exclusively to Colletotrichum truncatum worldwide, including Brazil (Ballhorn et al. 2010; Carvalho et al. 2015; Cavalcante et al. 2012; Damm et al. 2009; Paula Júnior et al. 1995). C. truncatum, which has curved conidia, was first described in association with lima bean anthracnose in the United States (Andrus and Moore 1935). In Brazil, C. dematium f. sp. truncata was reported in association with lima bean anthracnose in Minas Gerais (Paula Júnior et al. 1995). Recently, three species with cylindrical conidia were shown to cause anthracnose on lima bean in northeast Brazil: C. plurivorum (Cavalcante et al. 2018), C. clivae, and C. fructicola (Sousa et al. 2017).

Species within the genus Colletotrichum are considered to be among the most important causes of diseases on several crops of

${ }^{\dagger}$ Corresponding author: M. P. S. Câmara; marcos.camara@ufrpe.br

Funding: This research was funded by the Conselho Nacional de Desenvolvimento Científico e Tecnológico grant number 301890/2016-1.

*The $\boldsymbol{e}$-Xtra logo stands for "electronic extra" and indicates that two supplementary tables are published online.

The author(s) declare no conflict of interest.

Accepted for publication 3 March 2019.

() 2019 The American Phytopathological Society economic interest such as fruit trees, legumes, and ornamental plants (Barbieri et al. 2017; Lima et al. 2015; Liu et al. 2016; Sharma and Shenoy 2016). Previously, the identification of Colletotrichum spp. was carried out based on morphological and cultural characteristics. However, morphological characteristics may vary according to environmental factors such as culture medium and temperature and have been shown to be misleading for species identification in Colletotrichum. Currently, identification of Colletotrichum spp. is performed using a polyphasic approach that combines morphological and cultural characteristics with multilocus phylogenetic analysis of DNA sequences (Cai et al. 2009; Cannon et al. 2012; Damm et al. 2009; Hyde et al. 2014). C. truncatum has been associated with lima bean anthracnose in the United States using a polyphasic approach (Damm et al. 2009). In contrast, the characterization of $C$. truncatum from lima bean in Brazil was done exclusively on the basis of morphological characteristics, using few isolates from only one location (Paula Júnior et al. 1995).

Currently, there are no studies regarding the prevalence of Colletotrichum spp. on lima bean among the main production areas in Brazil. Therefore, the present study aimed to characterize the diversity, prevalence, and virulence of Colletotrichum spp. associated with anthracnose on lima bean in Brazil.

\section{Materials and Methods}

Sampling, isolation, and distribution of species. In 2015, leaves, branches, and pods with typical anthracnose symptoms were collected from lima bean crops in the following states in Northeast Brazil: Alagoas (one city), Ceará (six cities), Paraíba (nine cities), Pernambuco (six cities), and Piauí (three cities). Seven leaves and two pods were sampled per plant and at least 10 plants were sampled per area.

Fragments of 4 to $5 \mathrm{~mm}$ were cut from the transition region between symptomatic and asymptomatic tissues. Fragments were surface sterilized in $70 \%$ alcohol for $30 \mathrm{~s}, 2 \%$ sodium hypochlorite for $1 \mathrm{~min}$, and rinsed three times in sterile distilled water. Fragments were plated on potato dextrose agar (PDA) supplemented with streptomycin sulfate $(0.5 \mathrm{~g} /$ liter $)$ and incubated at $25^{\circ} \mathrm{C}$ with a $12-\mathrm{h}$ photoperiod. Colonies were observed daily to check the emergence of fungal colonies. Colonies similar in morphology to Colletotrichum spp. (Sutton 1980) were transferred to PDA and preserved in cryogenic tubes containing autoclaved distilled water at room temperature. Isolates were deposited to the culture collection of the Federal Rural University of Pernambuco, Collection of Phytopathogenic Fungi “Professora Maria Menezes", Recife, Pernambuco, Brazil. 
DNA extraction, polymerase chain reaction amplification, and DNA sequencing. For genomic DNA extraction, isolates were grown on PDA for 7 days at $27^{\circ} \mathrm{C}$ with a 12 -h photoperiod. The aerial mycelium was scraped off the colony surface and DNA was extracted using the protocol described by Möller et al. (1992), with minor changes. The DNA concentration was estimated visually on a $0.8 \%$ agarose gel.

A portion of the glyceraldehyde 3-phosphate dehydrogenase (GAPDH) gene was sequenced for all isolates to select representatives for multilocus analysis. The GAPDH was chosen because it has been identified as among the most variable markers that amplify across multiple Colletotrichum spp. complexes (Hyde at al. 2014). A multiple sequence alignment was used to generate a distance tree using the neighbor-joining algorithm in MEGA v.7 (Kumar et al. 2016) to identify phylotypes. Isolates that clustered in terminal clades with support equal to or greater than $75 \%$ were considered a single phylotype. Partial sequences of actin (ACT) and $\beta$-tubulin (TUB2) and the complete internal transcribed spacer (ITS) of nuclear ribosomal DNA were amplified and sequenced for all representative phylotypes. Primers used in the present study are listed in Supplementary Table S1.

Polymerase chain reactions (PCR) were run in a final volume of $50 \mu \mathrm{l}$ containing $32.8 \mu \mathrm{l}$ of water, $1 \mu \mathrm{l}$ of DNA, $2.0 \mu \mathrm{l}$ of each primer, $0.2 \mu \mathrm{l}$ of Taq DNA polymerase, $3 \mathrm{mM} \mathrm{MgCl}_{2}, 25 \mathrm{mM}$ each $\mathrm{dNTP}$, and $2.0 \mu \mathrm{l}$ of dimethyl sulfoxide. Reactions were performed on the MaxiGene Therm-1001 thermal cycler (Axygen, Tewksbury, MA, U.S.A.) using the following cycles: initial denaturation of $95^{\circ} \mathrm{C}$ for $3 \mathrm{~min}$; followed by 35 cycles of $95^{\circ} \mathrm{C}$ for $30 \mathrm{~s}, 56^{\circ} \mathrm{C}(\mathrm{GAPDH})$ or $55^{\circ} \mathrm{C}$ (ACT, ITS, and TUB2) for $1 \mathrm{~min}$, and $72^{\circ} \mathrm{C}$ for $90 \mathrm{~s}$; and a final extension at $72^{\circ} \mathrm{C}$ for $10 \mathrm{~min}$. Amplified PCR products were observed by gel electrophoresis in $1.5 \%$ agarose. PCR products were purified using the AxyPrep PCR Cleanup kit (Axygen) following the manufacturer's instructions. The regions were sequenced in both directions using ABI 3730 XL sequencer at Macrogen, Inc. (Seoul, South Korea). Sequences generated in the present study were deposited to GenBank (Supplementary Table S2).

Phylogenetic analysis. Sequences were assembled using the Staden package (Staden et al. 1998). For approximate species identification, the sequences were compared with GenBank sequences using BLAST to query the National Center for Biotechnology Information sequence database. Sequences of ex-type isolates were obtained from GenBank. Multiple sequence alignments of each independent locus were estimated using the Muscle algorithm implemented in MEGA v.7 and adjusted manually when necessary. For the multilocus analysis, the loci were concatenated using SequenceMatrix v.1.8 (Vaidya et al. 2011).

Phylogenetic reconstruction for each locus and the concatenated data set was performed using maximum-likelihood (ML) and Bayesian Inference (BI). ML analysis and BI were performed on the CIPRES Science Gateway portal (https://www.phylo.org/portal2/home.action) using RAXML-HPC2 (Stamatakis 2014) and MrBayes v. 3.2.6 (Ronquist et al. 2012), respectively. ML tree searches were performed assuming that sequences evolved according to the GTRGAMMA model and support values were estimated with 1,000 pseudoreplicates ( $-m$ GTRGAMMA $-p 12345-k-f a$ $-N 1,000-x$ 12345). For BI, the best-fit nucleotide substitution models were selected using the program MrModeltest 2.3 (Nylander 2004). Three simultaneous Markov chains were run for $30 \times 10^{6}$ generations with samples taken from the posterior every 1,000 generations. Convergence of all parameters was checked using Tracer v.1.5 (Rambaut and Drummond 2007) and the first 25\% of generations were discarded as burn-in. Alignments and trees were deposited in TreeBase (study ID S23810).

Species assignment. Phylogenetic species recognition was performed using the Genealogical Concordance Phylogenetic Species Recognition (GCPSR) criteria (Dettman et al. 2003). A clade was considered an independent lineage when it met at least one of two criteria: genealogical concordance or genealogical nondiscordance. The genealogical concordance criterion is satisfied if the clade is present in most individual gene trees. The criterion of genealogical nondiscordance is reached when a clade is strongly supported by at least one locus in both ML and BI analysis ( $\geq 70 \%$ and $\geq 0.95$, respectively), and not contradicted in any other individual gene tree with the same level of support. Novel species were recognized if the clade was recognized as a phylogenetic species by the GCPSR criterion, was strongly supported in both ML and BI analyses of the concatenated matrix, and did not contain the type of any previously described species.

Prevalence of Colletotrichum spp. The prevalence of Colletotrichum spp. by sampling geography (state) and host organ was recorded as a percentage of the total number of isolates per sampling strata. The prevalence of each species by state was calculated as the total number of isolates per species in a state divided by the total number of isolates from that state and expressed as a percentage. The prevalence of each species by host organ was expressed as a percentage of the total number of isolates of a species from a given host organ divided by the total number of isolates of that species across all host organs.

Pathogenicity and virulence of isolates. Lima bean plants (variety Branca) were inoculated 40 days after sowing for pathogenicity and severity assays. Representative isolates of each species were used to inoculate two leaves per plant. For each isolate, five plants were inoculated and each leaf was considered one replicate. For the preparation of the suspension, the isolates were grown on PDA at a temperature of $27^{\circ} \mathrm{C}$ with a 12-h photoperiod for spore production. The inoculation was performed by spraying the dorsal and ventral surface of the leaf with approximately $2 \mathrm{ml}$ of the suspension $\left(10^{5}\right.$ spores $/ \mathrm{ml}$ ) on each side. Plants were covered with plastic bags for $36 \mathrm{~h}$ to maintain high humidity and kept at a temperature of $27^{\circ} \mathrm{C}$ with a 12-h photoperiod in a growth chamber. Pathogenicity was verified 5 days after inoculation by the presence or absence of symptoms. Severity was evaluated using the scale developed by Carvalho (2009), where $0=$ absence of symptoms; $1=$ up to $10 \%$ of leaf area affected; $2=11$ to $25 \%$ of the leaf area affected; $3=$ 26 to $50 \%$ of leaf area affected, no leaflet drop; $4=51$ to $75 \%$ of leaf area affected, with or without leaflet drop; and $5=$ from 76 to $100 \%$ of leaf area affected, with or without two to three leaflets dropping. Differences in severity among species were evaluated by the Kruskal-Wallis test (significant at $P \leq 0.05$ ) using Statistix v.10 (Statistix 2013).

\section{Results}

Sampling and isolation. In total, 126 isolates with morphological characteristics similar to the genus Colletotrichum were obtained from lima bean. Of these isolates, 55 were from the state of Paraíba, 29 from Pernambuco, 20 from Ceará, 13 from Piauí, and 9 from Alagoas. In all, 91 isolates were obtained from leaves, 26 from pods, 3 from stems, and 3 from seed.

Phylogenetic analysis. A preliminary analysis of nucleotide variation among the 126 isolates using partial sequences of GAPDH revealed nine distinct phylotypes (H1 to $\mathrm{H} 9$ ). Three phylotypes $(\mathrm{H} 1, \mathrm{H} 2$, and $\mathrm{H} 3)$ were represented by 3,57 , and 13 isolates respectively, and the sequences were similar to sequences of the $C$. truncatum species complex according to a BLAST search. In total, 23 isolates ( $\mathrm{H} 4, \mathrm{H} 5, \mathrm{H} 6$, and $\mathrm{H} 7)$ were similar to sequences of $C$. brevisporum, 27 isolates (H8) were similar to C. cliviae, and 3 isolates (H9) to $C$. cliviae and C. orchidearum. According to the geographical origin, 36 representative isolates were chosen from GAPDH phylotypes to sequence the remaining loci. In all, 13 isolates of phylotypes $\mathrm{H} 1, \mathrm{H} 2$, and $\mathrm{H} 3 ; 15$ isolates of phylotypes $\mathrm{H} 4, \mathrm{H} 5, \mathrm{H} 6$, and $\mathrm{H} 7 ; 5$ isolates of haplotype $\mathrm{H} 8$; and 3 isolates of haplotype $\mathrm{H} 9$ were selected.

The selected isolates were distributed among five clades well supported in ML and BI multilocus analyses (Fig. 1). Most clades were recovered in the majority of the individual gene trees; however, only TUB2 and GAPDH trees presented strong support.

Species assignment. Colletotrichum lima bean isolates were assigned to four species according to GCPSR. Thirteen isolates clustered within the $C$. truncatum clade with maximum support in the ML and BI multilocus analyses. $C$. truncatum was recovered as 
monophyletic in all individual gene trees but was only strongly supported as such in the TUB2 and ITS gene trees.

Fifteen isolates belong to the C. magnum species complex, four of which are nested within the clade of $C$. brevisporum and three nested within the $C$. lobatum clade, all with strong support in multilocus analyses. $C$. lobatum and $C$. brevisporum were strongly supported as monophyletic by GAPDH and TUB2, respectively, and no discordance was observed among individual gene trees. Eight isolates representing five newly recognized lineages within the $C$. magnum species complex which are not associated with any previously described species were assigned to Colletotrichum lineage 1 (one isolate), Colletotrichum lineage 2 (two isolates), Colletotrichum lineage 3 (one isolate), Colletotrichum lineage 4 (two isolates), and Colletotrichum lineage 5 (three isolates). We decided not to describe these five lineages of Colletotrichum as new species due to recent taxonomic changes in the $C$. magnum complex and because some of the lineages are represented by single isolates.

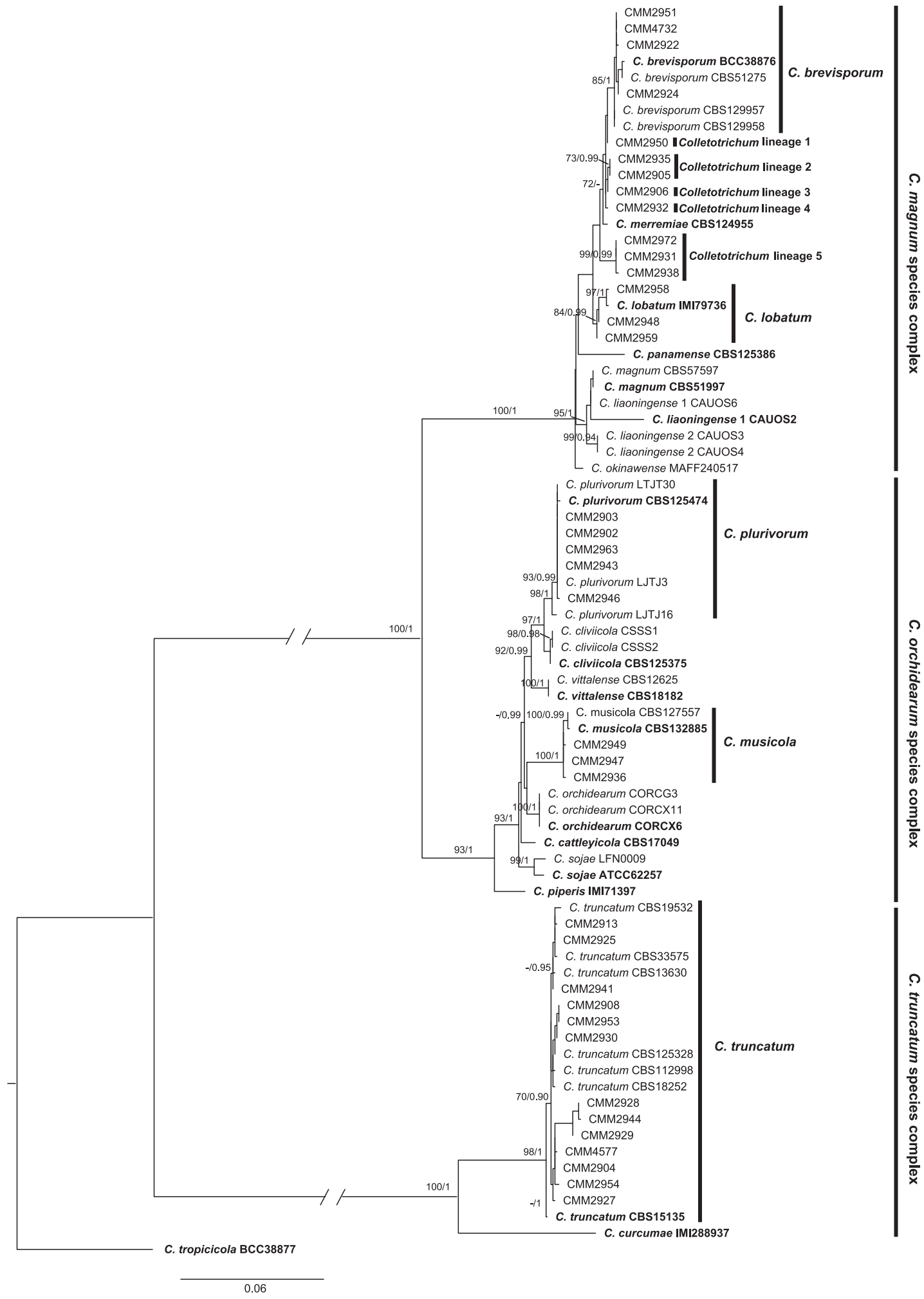

Fig. 1. Maximum-likelihood tree of Colletotrichum spp. inferred from a concatenated alignment of the following genes: actin, $\beta$-tubulin, glyceraldehyde 3-phosphate dehydrogenase, and internal transcribed spacer. Branch support values for maximum-likelihood and Bayesian inference are shown above the branches. Ex-type isolates are in bold font. Colletotrichum tropicicola was used as an outgroup. 
Finally, eight isolates belong to the $C$. orchidearum complex, five of which are nested within the $C$. plurivorum clade and three in the $C$. musicola clade. The two clades are strongly supported in multilocus analyses and can be retrieved in all individual gene trees with a high level of support.

Each species was represented by multiple isolates and, in the case of C. truncatum, multiple GAPDH phylotypes. C. truncatum represented 73 of the 126 isolates and was represented by three GAPDH phylotypes ( $\mathrm{H} 1=3$ isolates, $\mathrm{H} 2=57$ isolates, and $\mathrm{H} 3=13$ isolates), whereas C. lobatum, C. brevisporum, C. plurivorum, and C. musicola were each represented by a single phylotype, containing 6 (H4), 5 (H5), 27 (H8), and 3 (H9) isolates, respectively. Isolates of lineages 1, 2, 3 and 4 belonged to a single phylotype H6 (eight isolates) and isolates of lineage 5 were represented by the phylotype $\mathrm{H} 7$ (four isolates).

Prevalence. $C$. truncatum was the dominant species (58\%) associated with lima bean, followed by C. plurivorum (21\%), C. lobatum (5\%), C. brevisporum (4\%) and C. musicola (2\%). The remaining undescribed lineages accounted for $10 \%$ of all isolates.

The prevalence of each species varied among states (Fig. 2A) but C. truncatum was the dominant species in each state: Ceará (100\%), Piauí (62\%), Paraíba (53\%), and Alagoas (56\%). C. truncatum was also the only species to be found in all states. In contrast, $C$. musicola (2\%) was restricted to the state of Paraíba along with Colletotrichum lineage 1. Colletotrichum lineage 3 was only found in the state of Pernambuco.

All species were found in leaves, with the exception of $C$. musicola. Colletotrichum lineage 1, C. truncatum, C. brevisporum, $C$. lobatum, and C. musicola were found in pods, while $C$. truncatum and $C$. plurivorum were found on both stems and leaves. $C$. truncatum was the only species found in seed. (Fig. 2B).
Pathogenicity and virulence. All isolates were pathogenic on lima bean leaves, producing anthracnose symptoms, but no symptoms were observed on the uninoculated control plants. Anthracnose symptoms did not differ among species. Significant differences $(P<$ 0.05 ) were observed among species with respect to virulence (Fig. 3). $C$. truncatum was significantly more virulent than the other species (C. brevisporum, C. lobatum, C. plurivorum, and C. musicola).

\section{Discussion}

This study represents the first survey of the species of Colletotrichum that cause anthracnose of lima bean in the main producing states of Brazil with a large number of isolates and integrating pathogenicity, virulence, and phylogenetic analysis. In this study, we found five Colletotrichum spp. causing anthracnose on lima bean: C. truncatum, C. brevisporum, C. lobatum, C. plurivorum, and $C$. musicola. C. brevisporum, C. lobatum, and C. musicola are reported for the first time on lima bean.

C. truncatum is the most economically important pathogen of lima bean among those agents of anthracnose sampled in this study. It not only was the most ubiquitous species in terms of its distribution across plant organs and geographic areas but also was the most virulent on lima bean of all the species recovered. This species is also associated with anthracnose on many other Fabaceous plants such as soybean, peanut, and cowpea (Damm et al. 2009) as well as solanaceous species such as pepper (Liu et al. 2016). This species was previously reported causing anthracnose on lima bean in the Brazilian states of Piauí and Alagoas (Carvalho 2009; Sousa et al. 2017) and has already been found causing anthracnose on soybean in different soybean-producing regions in Brazil (Silva et al. 2017). The present study reports the presence of $C$. truncatum in three other states in northeast Brazil (Paraíba,
A

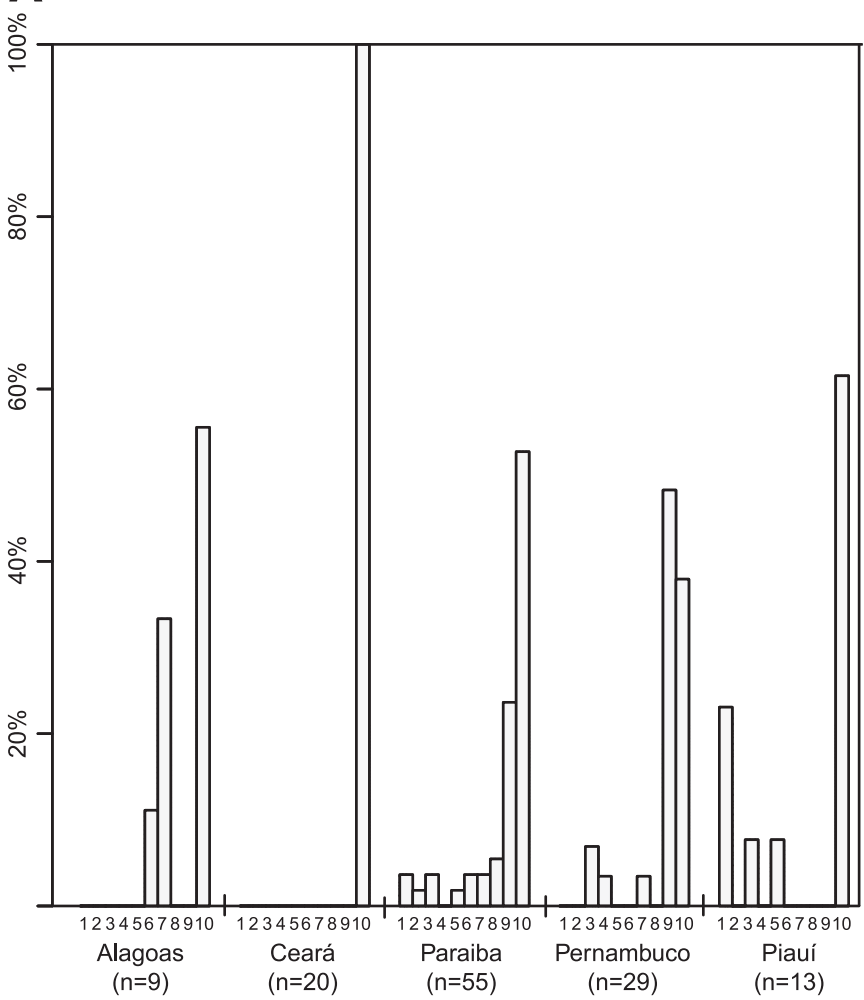

1 - C. brevisporum

2 - Colletotrichum sp. L1

3 - Colletotrichum sp. L2

4 - Colletotrichum sp. L3

5 - Colletotrichum sp. L4
B

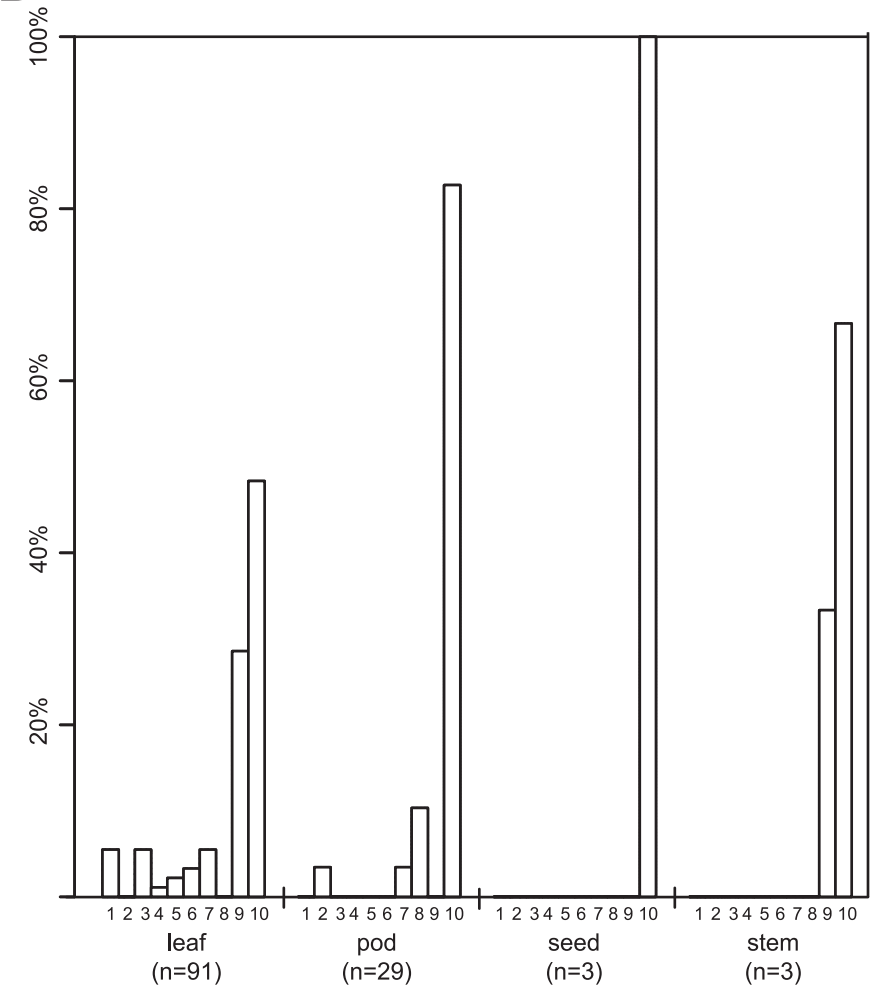

6 - Colletotrichum sp. L5

7 - C. lobatum

8 - C. musicola

9 - C. plurivorum

10 - C. truncatum

Fig. 2. A, Isolation rate (\%) of Colletotrichum spp. causing anthracnose in lima bean according to the state of origin. B, Prevalence (\%) of Colletotrichum spp. causing anthracnose in lima bean according to the plant organ sampled. 
Pernambuco, and Ceará) and three other species that cause anthracnose in lima bean based on more intensive sampling.

C. brevisporum, C. lobatum, C. plurivorum, and C. musicola were all capable of causing anthracnose on lima bean but were less virulent than C. truncatum (Fig. 3). However, C. lobatum is more virulent than both $C$. brevisporum and $C$. musicola and is considered here to be the second most virulent species on lima bean. $C$. lobatum, first found on Piper catalpaefolium in Trinidad and Tobago (Damm et al. 2018), was isolated from leaves and pods of lima bean and isolated from three of the five sampled states (Fig. 2A and B).

C. brevisporum was isolated from leaves and pods in two of the five sampled states (Fig. 2A and B). C. brevisporum was first reported causing anthracnose on Neoregelia sp. and Pandamus pygmaeus in Thailand (Noireung et al. 2012). It was later found causing anthracnose on papaya (Vieira et al. 2013) and chayote (Bezerra et al. 2016) in Brazil, in the states of Pernambuco and Santa Catarina, respectively. C. brevisporum has been also been found causing anthracnose on pepper (Capsicum spp.) in China (Liu et al. 2016) and in Brazil in the states of Manaus (De Almeida et al. 2017), Alagoas, Pernambuco, and Sergipe (Silva et al. 2017). Our study extends the distribution of this species to the states of Paraíba and Piauí.

C. plurivorum was found in two states causing symptoms on leaves and stems (Fig. 2A and B). Although C. plurivorum was dominant in Pernambuco, the significant difference in virulence between $C$. plurivorum and $C$. truncatum suggests that $C$. truncatum has greater relative fitness on lima bean and may become the dominant species in Pernambuco. This species, first described as $C$. sichuanensis, has only been reported causing anthracnose on pepper in China and, recently, anthracnose on lima bean in Brazil (Cavalcante et al. 2018; Damm et al. 2018; Liu et al. 2016).

C. musicola was described causing anthracnose on Musa spp. in Mexico (Damm et al. 2018). Despite being considered host specific, this species was found causing anthracnose on lima bean pod in the state of Paraíba (Fig. 3), although it was the least virulent of the species found.

Our work represents an important contribution to a precise understanding of the etiology and prevalence of anthracnose on fava bean in Brazil, using a large number of isolates collected in the five states that are the largest producers of lima bean in northeastern Brazil. The occurrence of several species causing anthracnose on lima bean may affect disease management, because different species might respond differently to various control strategies. Due to the broad distribution of $C$. truncatum in the main production areas and its greater virulence in relation to the other species, more epidemiological studies are necessary to better understand this pathological system. These findings are important for determining the best way to manage the disease.

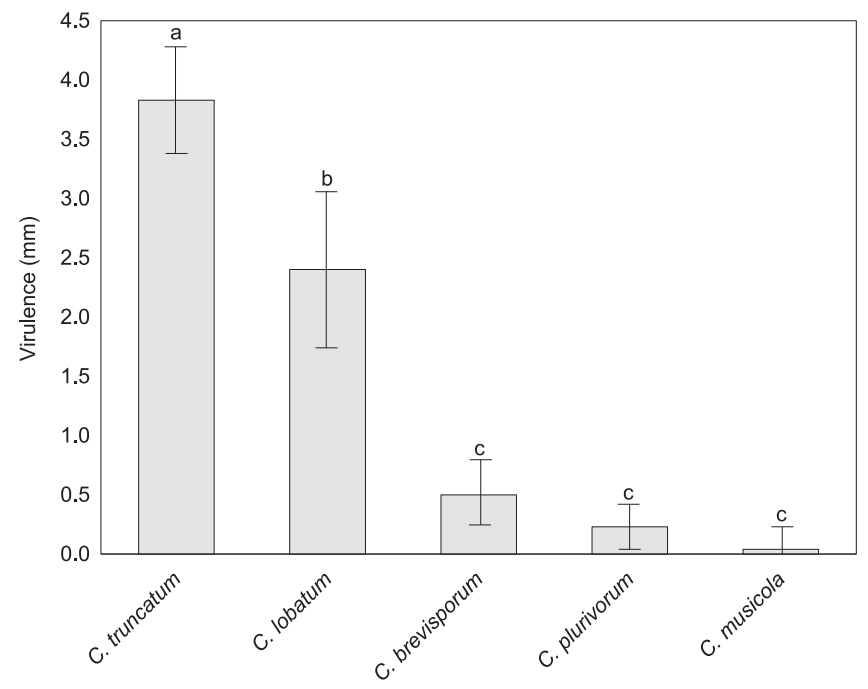

Fig. 3. Virulence of Colletotrichum spp. on lima bean on the fifth day after inoculation. Averages followed by the same letter are statistically the same by the Tukey test at $0.05 \%$.

\section{Acknowledgments}

We thank the Universidade Federal do Piauí and Dr. José Evando Beserra Júnior for the space provided for the elaboration of the experiments. M. P. S. Câmara and S. J. Michereff are research productivity fellows of the Conselho Nacional de Desenvolvimento Científico e Tecnológico (CNPq).

\section{Literature Cited}

Andrus, C. F., and Moore, W. D. 1935. Colletotrichum truncatum (Schw.), n. comb., on garden and lima beans. Phytopathology 25:121-125.

Ballhorn, D. J., Pietrowski, A., and Lieberei, R. 2010. Direct trade-off between cyanogenesis and resistance to a fungal pathogen in lima bean (Phaseolus lunatus L.). J. Ecol. 98:226-236.

Barbieri, M. C. G., Ciamoi-Guillardil, M., Moraes, S. R. G., Bonaldo, S. M., Rogério, F., Linhares, R. R., and Massola, N. S., Jr. 2017. First report of Colletotrichum cliviae causing anthracnose on soybean in Brazil. Plant Dis. 101:1677.

Bezerra, J. P., Ferreira, P. V., Barbosa, L. F., Ramos-Sobrinho, R., Pinho, D. B., Reis, A., Assunção, I. P., and Lia, G. S. A. 2016. First report anthracnose chayote fruits (Sechium edule) caused by Colletotrichum brevisporum. Plant Dis. 100:217.

Cai, L., Hyde, K. D., Taylor, P. W. J., Weir, B. S., Waller, J., Abang, M. M., Zhang, J. Z., Yang, Y. L., Phoulivong, S., Liu, Z. Y., Prihastuti, H., Shivas, R. G., McKenzie, E. H. C., and Johnston, P. R. 2009. A polyphasic approach for studying Colletotrichum. Fungal Divers. 39:183-204.

Cannon, P. F., Damm, U., Johnston, P. R., and Weir, B. S. 2012. ColletotrichumCurrent status and future directions. Stud. Mycol. 73:181-213.

Carvalho, E. M. S. 2009. Antracnose em feijão-lima (Phaseolus lunatus L.): Caracterização do agente causal e reação de genótipos a Colletotrichum truncatum. Universidade Estadual Paulista, Faculdade de Ciências Agrárias e Veterinárias, Jaboticabal, Brazil

Carvalho, E. M. S., Beserra, J. E. A., Jr., and Barguil, B. M. 2015. Lima bean diseases. Pages 113-133 in: Phaseolus lunatus: Diversity, Growth and Production. A. C. A. Lopes and R. L. F. Gomes, Org. A. S. A. Ferreira, ed Nova Science Publishers, New York, NY, U.S.A.

Cavalcante, G. R. S., Carvalho, E. M. S., Gomes, R. L. F., Santos, A. R. B., and Santos, C. M. P. M. 2012. Reação de subamostras de feijão-lima à antracnose. Summa Phytopathol. 38:329-333.

Cavalcante, G. R. S., Vieira, W. A. S., Michereff, S. J., Barguil, B. M., Doyle, V. P., and Câmara, M. P. S. 2018. First report of anthracnose caused by Colletotrichum sichuanensis on Phaseolus lunatus in Brazil. Plant Dis. 102:680.

Damm, U., Sato, A., Alizadeh, A., Groenewald, J. Z., and Crous, P. W. 2018. The Colletotrichum dracaenophilum, C. magnum and $C$. orchidearum species complexes. Mycol. 92:1-46.

Damm, U., Woudenberg, J. H. C., Cannon, P. F., and Crous, P. W. 2009 Colletotrichum species with curved conidia from herbaceous hosts. Fungal Divers. 39:45-87.

de Almeida, L. B., Matos, K. S., Assis, L. A. G., Hanada, R. E., and da Silva, G. F. 2017. First report of anthracnose of Capsicum chinense in Brazil caused by Colletotrichum brevisporum. Plant Dis. 101:1035.

Dettman, J. R., Jacobson, N. D. J., and Taylor, J. W. 2003. A multilocus genealogical approach to phylogenetic species recognition in the model eukaryote Neurospora. Evolution 57:2703-2720.

Hyde, K. D., Nilson, R. H., Alias, S. A., Ariyawansa, H. A., Blair, J. E., Cai, L., Cock, A. W. A. M., Dissanayake, A. J., Glockling, S. L., Goonasekara, I. D., Gorczak, M., Hahn, M., Jayawardena, R. S., Van Kan, J. A. L., Laurence, M. H., Lévesque, C. A., Li, X., Liu, J. K., Maharachchikumbura, S. S. N., Manamgoda, D. S., Martin, F. N., Mckenzie, E. H. C., Mctaggart, A. R., Mortiner, P. E., Nair, P. V. R., Pawlowska, J., Rintoul, T. L., Shivas, R. G., Spies, C. F. J., Summerell, B. A., Taylor, P. W. J., Terhem, R. B., Udayanga, D. Vaghefi, N., Walther, G., Wilk, M., Wrzosek, M., Xu, J. C., Yan, J., and Zhou, N. 2014. One stop shop: Backbones trees for important phytopathogenic genera: I (2014). Fungal Divers. 67:21-125.

Instituto Brasileiro de Geografia e Estatística. 2017. Produção Agricola 2016. Rio de Janeiro. ftp://ftp.ibge.gov.br/Producao_Agricola/Levantamento_Sistematico_da_ Producao_Agricola_[mensal]/Comentarios/lspa_201606comentarios.pdf

Kumar, S., Stecher, G., and Tamura, K. 2016. MEGA7: Molecular Evolutionary Genetics Analysis version 7.0 for bigger datasets. Mol. Biol. Evol. 33: 1870-1874.

Lima, N. B., Lima, W. G., Tovar-Pedraza, J. M., Michereff, S. J., and Câmara M. P. S. 2015. Comparative epidemiology of Colletotrichum species from mango in northeastern Brazil. Eur. J. Plant Pathol. 141:679-688.

Liu, F., Tang, G., Zheng, X., Li, Y., Sun, X., Qi, X., Zhou, Y., Xu, J., Chen, H., Chang, X., Zhang, S., and Gong, G. 2016. Molecular and phenotypic characterization of Colletotrichum species associated with anthracnose diseases in peppers from Sichuan Province China. Sci. Rep. 6:32761.

Maquet, A., Vekemans, X., and Baudoin, J. P. 1999. Phylogenetic study on wild allies of lima bean, Phaseolus lunatus (Fabaceae), and implications on its origin. Plant Syst. Evol. 218:43-54.

Möller, E. M., Bahneg, G., Sandermann, H., and Geiger, H. H. 1992. A simple and efficient protocol for isolation of high molecular weight DNA from filamentous fungi, fruit bodies and infected plant tissues. Nucleic Acids Res. 20:6115-6116

Noireung, P., Phoulivong, S., Liu, F., Cai, L., McKenzie, E. H. C., Chukeatirote, E., Jones, E. B. G., Bahkali, A. H., and Hyde, K. D. 2012. Novel species of 
Colletotrichum revealed by morphology and molecular analysis. Mycologie 33: 347-362.

Nylander, J. A. A. 2004. MrModeltest v2. Program distributed by the author. Evolutionary Biology Centre, Uppsala University, Uppsala, Sweden.

Paula Júnior, T. J., Silva, M. B., and Vieira, R. F. 1995. Doenças causadas por fungos em hortaliças leguminosas. Inf. Agropec. 17:63-71.

Rambaut, A., and Drummond, A. 2007. Tracer v. 1.4. University of Oxford, Oxfordshire, U.K. http://tree.bio.ed.ac.uk/software/tracer/

Ronquist, F., Teslenko, M., Van Der Mark, P., Darling, A., Hohna, S., Larget, B., Liu, L., Suchard, M. A., and Huelsenbeck, J. P. 2012. MrBayes v. 3.2: Efficient Bayesian phylogenetic inference and model choice across a large model space. Syst. Biol. 61:539-542.

Sharma, G., and Shenoy, B. D. 2016. Colletotrichum systematics: Past, present and prospects. Mycosphere 7:1093-1102.

Silva, J. R. A., Chaves, T. P., Silva, A. R. G., Barbosa, L. F., Costa, J. F. O., Ramos-Sobrinho, R., Teixeira, R. R. O., Silva, S. J. C., Lima, G. S. A., and Assunção, I. P. 2017. Molecular and morpho-cultural characterization of Colletotrichum spp. associated with anthracnose on Capsicum spp. in northeastern Brazil. Trop. Plant Pathol. 42:315-319.
Sousa, S. S., Silva, R. A. S., Assunção, I. P., Melo, P. M., Feijó, F. M., Matos, K. S., Lima, G. S. A., and Beserra, E. A. B., Jr. 2017. Colletotrichum species causing anthracnose on lima bean in Brazil. Trop. Plant Pathol. 38:329-333.

Staden, R., Beal, K. F., and Bonfiels, J. K. 1998. The Staden package. Pages 115-130 in: Bioinformatics Methods and Protocols. S. Misener and S. A. Krawetz, eds. Humana Press Inc., Totowa, NJ.

Stamatakis, A. 2014. RAxML version 8: A tool for phylogenetic analysis and post-analysis of large phylogenies. Bioinformatics 30:1312-1313.

Statistix. 2013. Statistix 10, Version 10. Analytical Software, Tallahassee, FL, U.S.A.

Sutton, B. C. 1980. The Coelomycetes: Fungi Imperfecti with Pycnidia, Acervuli and Stromata. Commonwealth Mycological Institute, Kew, Surrey, U.K.

Vaidya, G., Lohman, D. J., and Meier, R. 2011. SequenceMatrix: Concatenation software for the fast assembly of multi-gene datasets with character set and codon information. Cladistics 27:171-180.

Vieira, W. A. S., Nascimento, R. J., Michereff, A. J., and Câmara, M. P. S. 2013. First report of papaya fruit anthracnose caused by Colletotrichum brevisporum in Brazil. Plant Dis. 97:1659. 